\title{
Selection on testis size as an indicator of maturity in growing animals. I Direct and correlated responses in growth
}

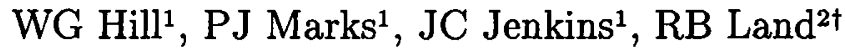

\author{
${ }^{1}$ Institute of Animal Genetics, University of Edinburgh, \\ West Mains Road, Edinburgh EH9 $3 J N$; \\ ${ }^{2} A F R C$ Institute of Animal Physiology and Genetics Research, \\ Edinburgh Research Station, Roslin, Midlothian EH25 9PS, UK
}

(Received 2 October 1989; accepted 15 February 1990)

\begin{abstract}
Summary - Selection was undertaken in mice to test whether gonad size, specifically testis weight, could be used to indicate degree of maturity and produce genetic change in the shape of the growth curve from records on young animals only. Selection was practised for 11 generations high and low on 5 wk male body weight (lines HX, LX), on 5 wk testis weight (XH, XL) and on indices with these traits selected in the same (HH, LL) and in opposite (HL, LH) directions. There were 2 replicates of each selection line and 4 unselected controls. Divergences between high and low lines within family standard deviation units for 5 wk body weight and testis weight, respectively, were: HX-LX: 1.8 and 2.3, XH-XL: 2.2 and 4.2, HH-LL: 1.9 and 3.4, and HL-LH, 2.0 and -2.7. There were minor changes in shape of the growth curve in the direction expected, with those selected for high testis weight showing earlier maturity. A simple measure, $6 \mathrm{wk}$ weight/15 wk weight (\%), for entire males was: HX 74.3, LX 67.3, XH 71.8, XL 69.6, HH 78.1, LL 72.6, HL 74.2, LH 78.5, averaging 76.1 for lines selected for high testis weight and 72.1 for low, compared to 74.0 for controls. In castrate males, a similar pattern of changes in growth curve was observed indicating that they were not a consequence of testis derived hormones. Mice selected for high testis weight were leaner than those selected for low testis weight. Thus, growth curves changed due to selection on testis weight, but it was not established if this is because testis size is an indicator of sexual maturity.
\end{abstract}

growth / maturity / testis / selection / mouse

Résumé - Sélection par la taille des testicules considérée comme un indicateur de la maturité des animaux en croissance. I Réponse directe et réponse corrélée sur les caractères de croissance. Une expérience de sélection a été réalisée chez la souris pour déterminer si la taille des gonades, en particulier la masse des testicules, pouvait indiquer le degré de maturité et pouvait modifier l'allure de la courbe de croissance, à partir des seules données recueillies chez de jeunes animaux. La sélection a été conduite pendant 11 générations, vers le haut $(H)$ et vers le bas $(L)$ selon plusieurs critères: masse

* Formerly AFRC Animal Breeding Research Organisation 
corporelle chez le mâle à 5 semaines (lignées $H X, L X$ ); masse testiculaire à 5 semaines ( $X H, X L)$; indices combinant ces deux caractères, dans le même sens (HH, LL) ou en sens opposés (HL, LH). Chaque lignée sélectionnée a été répétée deux fois, et \& lignées témoins non sélectionnées ont été élevées. Mesurées en unités d'écart type intrafamille, les divergences observées entre lignées haute et basse ont été les suivantes, respectivement pour la masse corporelle et la taille des testicules: $H X-L X: 1,8$ et 2,3; XH-XL:2,2 et 4,2; HH-LL: 1,9 et 3,4; HL-LH: 2,0 et -2,\%. On a observé de petites différences de la forme des courbes de croissances dans le sens attendu, les lignées sélectionnées pour une masse testiculaire élevée montrant une maturité plus précoce. Le rapport de la masse corporelle à 6 semaines sur celle à 15 semaines était chez les mâles entiers (en pourcentage): $H X$ : 74,$3 ; L X: 67,3 ; X H: 71,8 ; X L: 69,6 ; H H: 78,1 ; L L: 72,6 ; H L: 74,2 ; L H: 78,5 ;$ avec une moyenne de 76,1 chez les lignées sélectionnées pour une masse testiculaire élevée, contre 72,1 chez celles sélectionnées pour une masse testiculaire faible, et 74,0 chez les lignées témoins. L'observation chez les mâles castrés de modifications similaires des courbes de croissance indique qu'elles ne sont pas dues aux hormones sécrétées par les testicules. Les souris des lignées sélectionnées pour une masse testiculaire élevée étaient plus maigres que celles sélectionnées pour une masse testiculaire faible. Des modifications des courbes de croissance induites par la sélection sur la masse testiculaire ont ainsi pu être observées, mais on n'a pas établi que c'était parce la masse testiculaire est un indicateur spécifique de la maturité sexuelle.

croissance / maturité / testicule / sélection / souris

\section{INTRODUCTION}

The animal breeders' aim is to select animals of high early growth but low mature size so as to reduce costs of both the slaughtered animal and its dam. Bone growth of animals slows or terminates after puberty under the influence of gonadal hormones, so the object of the experiment was to test whether selection on body weight and testis weight on the immature animal could be used to influence both early gains and mature weights. This follows results in sheep, where selection on testis weight of rams with phenotypic correction for body weight led to correlated changes in mature weights in their female relatives, high testis weight being associated with low body weight, and vice versa (Land et al, 1980; Lee and Land, 1985; Haley et al, 1989 (submitted); Lee and Haley, 1990).

The present approach differs from the more direct method of selecting directly on weight at different ages which has been applied with varying success in different species. Substantial bending of the growth curve has been achieved in both turkeys (Abplanalp et al, 1963) and chickens (Ricard, 1975). In mice, bending has been effected, but to a lesser extent than in poultry, by McCarthy and Doolittle (1977), who selected on 5 and 10 wk weight with the objective, inter alia, of increasing 5 and holding $10 \mathrm{wk}$ weight constant, by Wilson (1973) who selected on the ratio of 3-6 wk gain to 3-9 wk gain, and by von Butler et al $(1980,1986)$ using 3-5 wk gain and $8 \mathrm{wk}$ weight. These schemes, however, require selection decisions to be deferred until animals approach their mature weight which is after the usual age of slaughter and often after the age of first mating, when culling decisions have to be made in both mice and domestic livestock.

In the present experiment, mice were selected high and low for body and testis weight on either trait alone or on indices of the 2 traits in either the same or the opposite direction, so as to produce a range of lines. Subsequently, body weights were recorded at a series of ages to assess the efficacy of the selection. As testis 
size may also be an indicator of ovulation rate and litter size (Land 1973), records of reproductive performance were kept and will be reported in a subsequent paper (Hill et al, 1990). Further details of the experiment are reported in $\mathrm{PhD}$ theses by Jenkins (née Williams, 1984) and Marks (1988).

\section{MATERIAL AND METHODS}

\section{Mouse stocks and housing}

The mice for generation 0 of this experiment were crosses at generation 3 or 4 between pairs of the unselected control lines of the $G$ strain established from a 3 -way cross of 2 inbred and 1 outbred strain (Sharp et al, 1984). Four separate sets of crosses were made to establish the different foundation groups. The mouse house was maintained at $21 \pm 1^{\circ} \mathrm{C}, \mathrm{RH} 30-40 \%$, with water and BP's rat and mouse No 1 expanded maintenance diet provided ad libitum.

\section{Selection lines}

Twenty lines were established as shown in table I, with 2 replicates of each of 8 selected lines and 4 replicates of the unselected controls. The lines were managed as 4 contemporary groups spaced at 3 wk intervals, each group comprising 4 selected lines (which were either the 4 single trait lines or the 4 index lines) and 1 control.

Table I. Selection lines and designation. Each line was replicated.

\begin{tabular}{llccc}
\hline Lines & \multicolumn{3}{c}{ Trait selected } & Designation \\
& \multicolumn{2}{l}{ Body weight } & Testis weight & \\
\hline \multirow{2}{*}{ Body weight } & High & Single trait lines & HX \\
Testis weight & Low & - & - & LX \\
Control & - & High & XH \\
& - & Low & XL \\
Index 1 & High & & - & CC \\
Index 2 & Low & & High & \\
Control & High & & Low & HH \\
& Low & Low & LL \\
& - & High & HL \\
& & & - & LH \\
\hline
\end{tabular}

Mice were mated at approximately 9 wk of age. Eight pair matings per line were made each generation, using the maximum avoidance scheme of Falconer (1973), together with 4 reserve matings which were only used if necessary. At birth, litter size was adjusted to between 6 and 10 young per litter by adding or removing young so as to reduce associated effects on growth. Within full sib family selection 
of males was practised, while females were taken at random within families, as were males in the controls. The selection phase of the experiment was continued for 12 generations, but no selection was practised in generation 7 .

A preliminary study showed that $5 \mathrm{wk}$ of age was an appropriate age for selection. Both body and testis are then growing rapidly and there is a high (0.99) correlation of right and left testis weight to allow hemicastration. The coefficients of variation of body weight and testis weight were then 0.17 and 0.26 respectively and their phenotypic correlation was 0.50 .

Body weight at 5 wk was recorded on all males. Testis weight at 5 wk was recorded every generation in lines selected on testis weight, but not every generation in the others (ie HX, LX and CC). To do this, mice were anaesthetised by Sagatal and hemicastrated, and 1 testis was excised and weighed. The indices used were

$$
I= \pm W / \sigma_{W} \pm T / \sigma_{T}= \pm 0.54 W \pm 0.112 T
$$

where $\mathrm{W}$ and $\mathrm{T}$ denote body weight $(\mathrm{g})$ and testis weight $(\mathrm{mg})$; and $\sigma_{\mathrm{W}}$ and $\sigma_{\mathrm{T}}$ denote their within family phenotypic standard deviations in generation 0 , estimated at $1.82 \mathrm{~g}$ and $8.9 \mathrm{mg}$ respectively. In line $\mathrm{HL}$, for example, mice were selected for high values of $I=0.54 W-0.112 T$ each generation.

\section{Data recorded}

Analyses of growth curves were made at generations 7 and 13, after 6 and 11 generations of selection, respectively. At generation 13, litters were standardized to 7 young at birth, and at $19 \mathrm{~d}$ half the male mice were castrated and dummy operations were undertaken on the rest. Eight entire and 8 castrated mice of each line were weighed, at least weekly from weaning at $3 \mathrm{wk}$ until they were $17 \mathrm{wk}$ old. Food intake was recorded at generation 13 on the same mice, who were caged in pairs and fed ad libitum. Gonadal fat pads and hind limb fat pads were dissected on 11 wk old entire males of generation 11, and chemical analysis of the whole minced carcass was undertaken on the mice of generation 13.

\section{Statistical analysis}

The experiment was basically a partial block design, with each block comprising 5 lines, each line replicated over 2 blocks. Apart from the block (group) effects which were taken as fixed, there were 2 other sources of error associated with a line mean: genetic drift accumulated over the selection and error due to recording limited numbers. This combined error variance was estimated as the interaction variance between selection line and replicate. Thus, the model used for observations taken only on males was

$$
Y_{g h i j}=u+T_{g}+R_{g h}+L_{g i}+R L_{g h i}+e_{g h i j^{\prime}}
$$

where: $\dot{Y}_{g h i j}$ is an observation on individual $j$ in replicate $h$ of line $i$ within the type of selection $g ; u$ is the overall mean; $T_{g}$ is the effect of type of selection ( $g=1$ for single trait, $g=2$ for index; $R_{g h}(h=1,2)$ is the effect of the $h$ th replicate nested within the $g$ th type of selection; $L_{g i}(i=1, \ldots, 5)$ is the effect of the line nested within type of selection; $R L_{g h i}$ is the replicate $\times$ line within type interaction, which was interpreted as the drift effect and was the predominant error used in tests, 
although with only $8 \mathrm{df}$; and $e_{g h i j}$ is the remainder, which in some analyses was partitioned to include a litter effect.

\section{RESULTS}

\section{Responses in 5 week body weight and testis weight}

Generation means for body weight and testis weight of $5 \mathrm{wk}$ old males are shown in figures 1-5. For clarity, results for pooled replicates are shown in the graphs, but in table II, differences between pairs of selected lines at the end of selection (means of generations 10,11 and 12) are shown for each replicate.
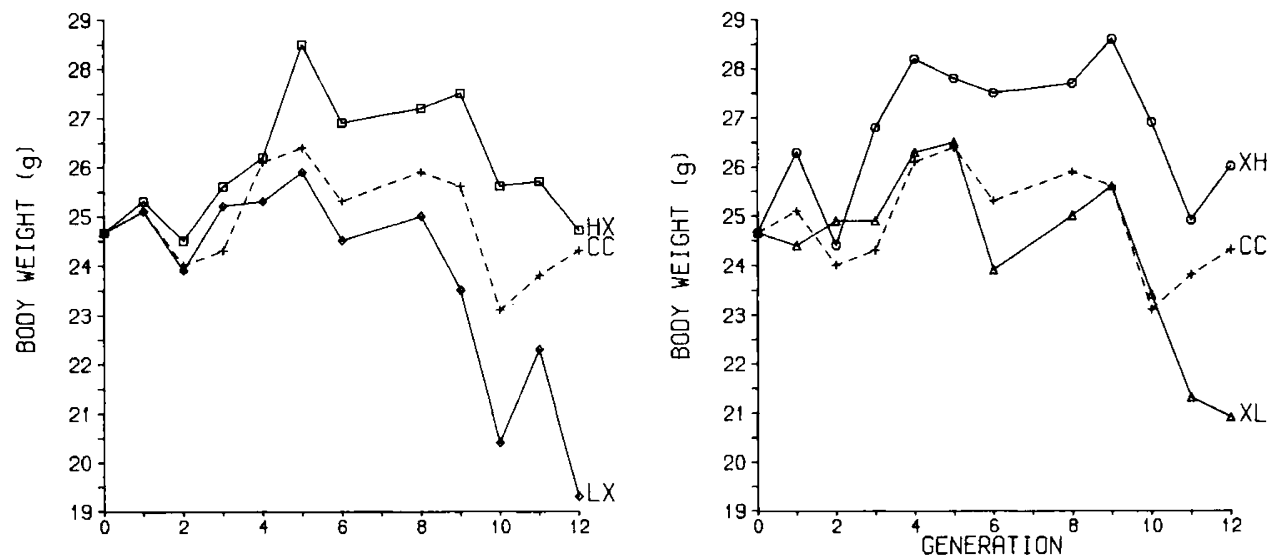

Fig 1. Five wk body weight in males of single trait lines with contemporary controls (CC) averaged over replicates: left graph, lines selected for body weight (HX, LX); right graph, lines selected for testis weight $(\mathrm{XH}, \mathrm{XL})$.

In the single trait lines there were direct responses (as divergence between high and low lines) of the order of 2 sd (within family standard deviations) for body weight and $4 \mathrm{sd}$ for testis weight, and similar positive correlated responses of about 2 sd in testis weight and body weight respectively. Thus, there were substantial positive correlated responses in index 1 , where body weight and testis weight have the same sign, and negative correlated responses in index 2 , albeit very small in the body weight lines. There was, however, substantial variation between replicates (table II), and, although selection differentials were similar in high and low lines, some asymmetry of response (figs 1-5). The replicate lines comprised only 8 mating pairs and so between replicate and direction, variation would be expected from genetic sampling. The analyses have therefore, to minimise their number, been based on divergence between high and low lines.

There were responses of the same order in the index 1 lines, ie about 3 sd in the index itself, with positive correlated responses of 2 and over 3 sd in body weight and testis weight respectively, and thus, since testis weight had changed relatively more, a negative correlated response was seen in index 2 . Although the results of the 

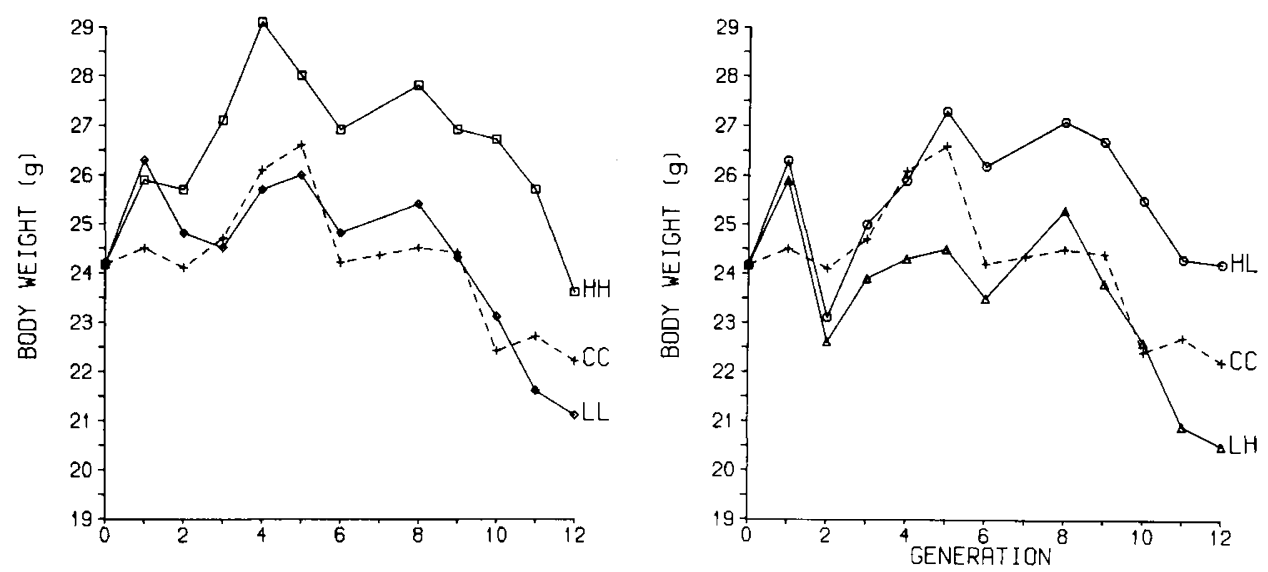

Fig 2. Five wk body weight in males of index lines: left graph, lines selected on index 1 (HH, LL); right graph, lines selected on index $2(\mathrm{HL}, \mathrm{LH})$. Otherwise as figure 1.
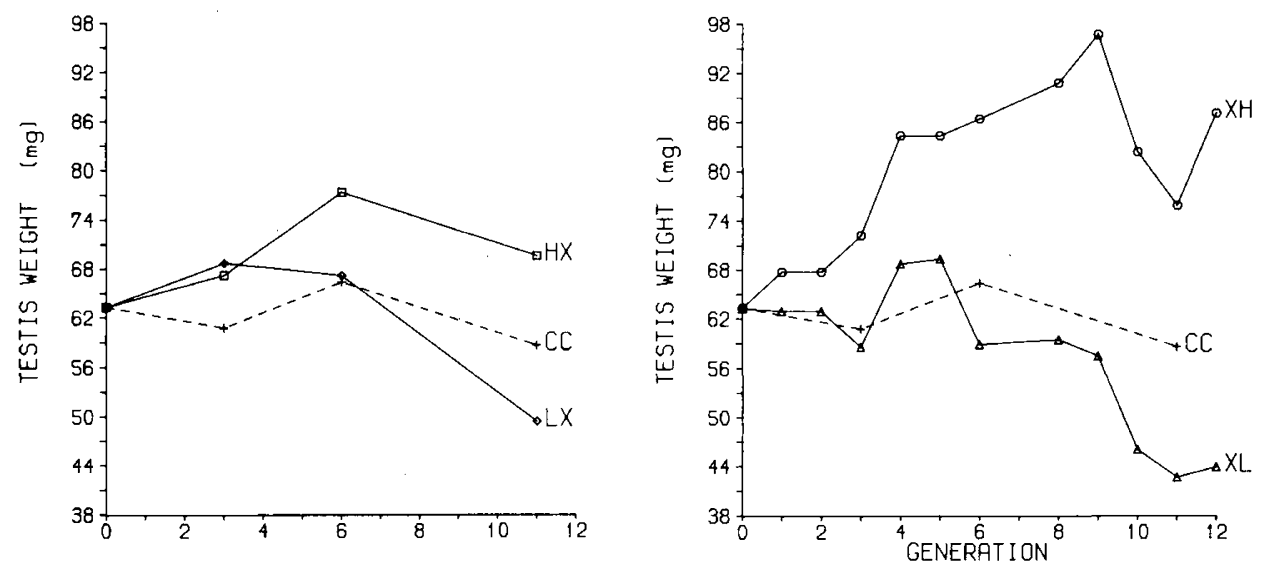

Fig 3. Five wk testis weight of single trait lines. Otherwise as figure 1.

single trait selection indicate a positive genetic correlation between the traits, with index 2 there was a substantial direct response of $4 \mathrm{sd}$ in the index and correlated responses of the order of $2 \mathrm{sd}$ of increasing body weight and decreasing testis weight.

Estimates of realized heritability from within family selection $\left(h_{w}^{2}\right)$ obtained from regression of divergence of response ( $e g \mathrm{HX}-\mathrm{LX}$ ) on cumulative within family section differential each generation are given in table III. Using the intra-class correlation estimate $(t)$ from the base population, estimates of heritability were obtained as $h^{2}=2(1-t) h_{w}^{2}$ (Falconer, 1989). Both $h_{w}^{2}$ and $h^{2}$ estimates were higher for testis weight and index 2, where antagonistic selection was practised, than for body weight and index 1 . Heritability estimates were lower than previously obtained for body weight in this population (Sharp et al, 1984) and testis weight on a different population (Islam et al, 1976) at later ages, 10 and 11 wk respectively. 

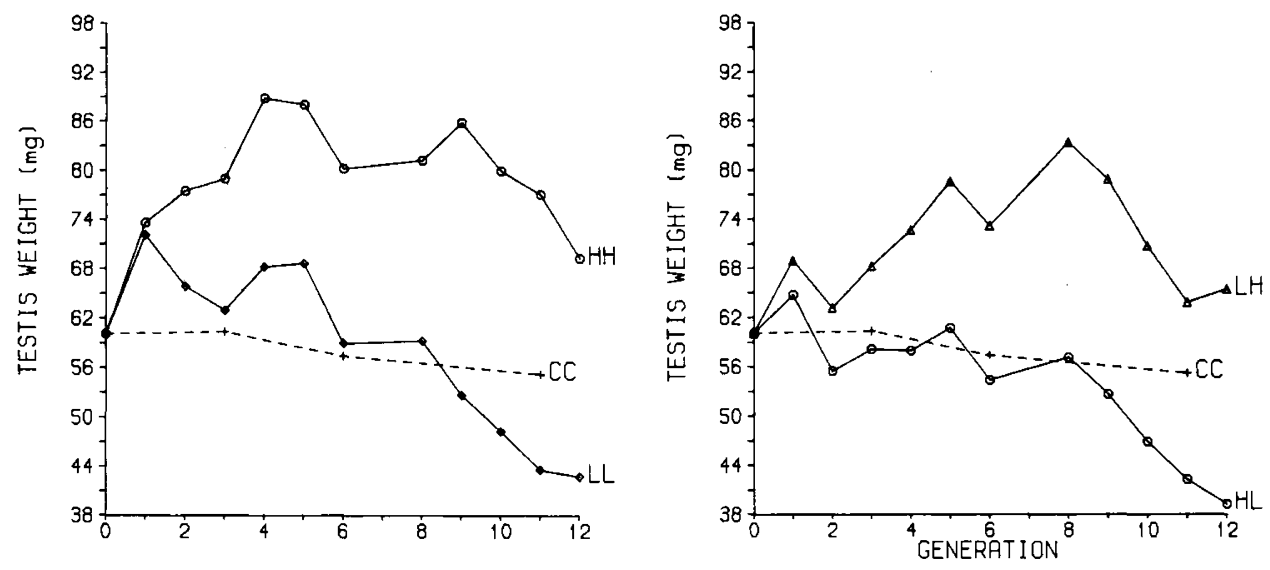

Fig 4. Five wk testis weight of index lines. Otherwise as figures 1 and 2.
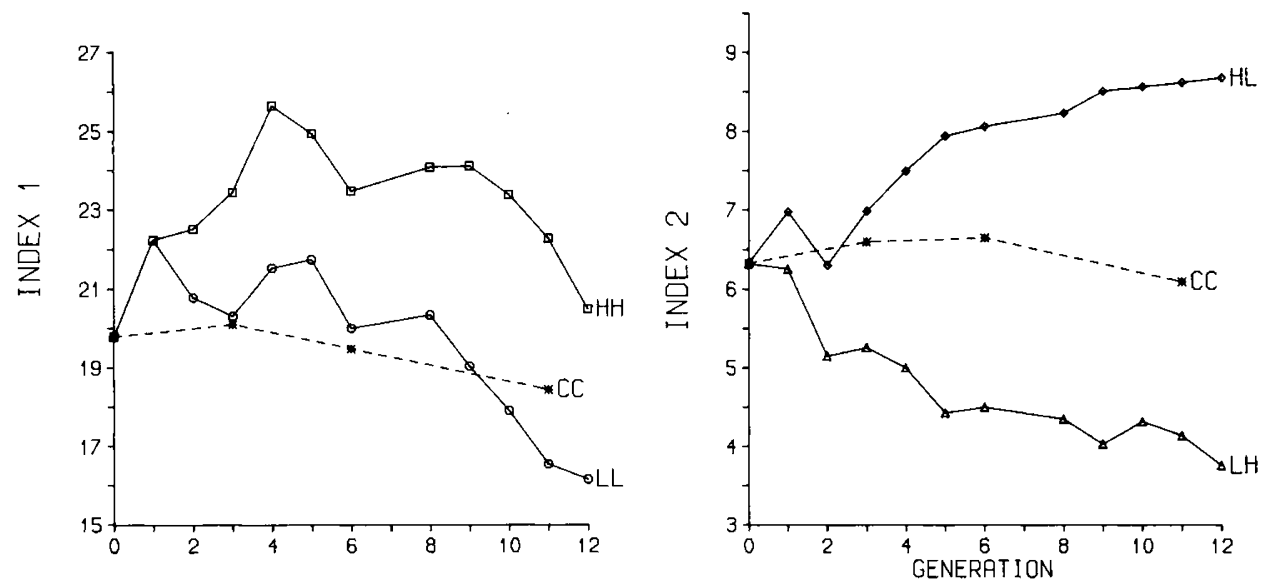

Fig 5. Index values of index selected lines (ie direct responses): left graph, index $1(0.54 \mathrm{~W}+0.112 \mathrm{~T}$ ) for lines selected on index 1 (HH, LL); right graph, index 2 $(0.54 \mathrm{~W}-0.112 \mathrm{~T})$ for lines selected on index $2(\mathrm{HL}, \mathrm{LH})$.

From the pairs of single trait selection lines an estimate of genetic correlation is readily obtained as $\left[\left(C_{T} C_{W}\right) /\left(R_{W} R_{T}\right)\right]^{1 / 2}$ where, for example, $R_{W}, C_{T}$ denote the direct response in body weight and correlated response in testis weight from selection on body weight (Falconer, 1989). From table II, the estimates of correlation are $0.85,0.49$ and 0.80 from replicates 1,2 and pooled, respectively. An estimate of the genetic correlation from the index lines can also be obtained, and the method of calculation is given in the Appendix. This estimate was 0.17 for replicates pooled. It is clear that the index selection was more effective in producing divergence of the traits in opposite directions, ie high body weight and low testis weight, than would be expected from the single trait lines. A further explanation of the higher 
Table II. Divergence between pairs of lines in $5 \mathrm{wk}$ body weight, $5 \mathrm{wk}$ testis weight and indices computed from means of generations 10,11 and 12 for each replicate and their average (Av), the latter also expressed in standard deviation units (sd) ${ }^{1} .{ }^{1}$ Expressed relative to the within family standard deviations in the base population, which for body weight, testis weight, Index 1 and Index 2 were $1.82 \mathrm{~g}, 8.9 \mathrm{mg}, 1.68$ units and 1.07 units, respectively; ${ }^{2}$ Index $1=0.54 W+0.112 T$, Index $2=0.54 W-0.112 T ;{ }^{3}$ Generation 11 means only for CC, HX and LX as testis weights were not recorded in generations 10 and 12. Mean body weights over generations 10, 11, 12 for HX-LX of rep 1 , rep 2 and rep Av were $4.9 \mathrm{~g}, 4.4 \mathrm{~g}$ and $4.6 \mathrm{~g}(=2.5 s d)$ respectively.

\begin{tabular}{lcllcc}
\hline Comparison & Rep & Bodywt(g) & Testis wt(mg) & Index $1^{2}$ & Index $2^{2}$ \\
\hline CC mean & & & & \\
HX-LX & & 23.2 & 57 & 18.9 & 6.2 \\
& 1 & 4.7 & 25 & 5.3 & -0.3 \\
& 2 & 2.0 & 16 & 2.8 & -0.6 \\
XH-XL & $\mathrm{Av}(\mathrm{sd})$ & $3.41(1.8)$ & $20(2.3)$ & $4.1(2.4)$ & $-0.4(-0.4)$ \\
& 1 & 7.4 & 55 & 10.2 & -2.2 \\
HH-LL & 2 & 0.6 & 20 & 2.5 & -1.8 \\
& $\mathrm{Av}(\mathrm{sd})$ & $4.0(2.2)$ & $37(4.2)$ & $6.4(3.8)$ & $-2.0(-1.9)$ \\
& 1 & 2.1 & 28 & 4.3 & -2.0 \\
HL-LH & 2 & 4.7 & 33 & 6.1 & -1.3 \\
& $\mathrm{Av}(\mathrm{sd})$ & $3.4(1.9)$ & $31(3.4)$ & $5.2(3.1)$ & $-1.6(-1.5)$ \\
& 1 & 4.6 & -20 & 0.2 & 4.8 \\
& 2 & 2.5 & -27 & -1.6 & 4.3 \\
& $\mathrm{Av}(\mathrm{sd})$ & $3.6(2.0)$ & $-24(-2.7)$ & $-0.7(-0.4)$ & $4.6(4.3)$ \\
\hline
\end{tabular}

Table III. Realized heritabilities for within full-sib family selection $\left(h_{w}^{2}\right)$ estimated from the regression of divergence of response between high and low lines on cumulative selection differential, and heritabilities $\left(h^{2}\right)$ predicted from $h_{w}^{2}$ and full-sib intra-class correlation $(t)$ estimates in the base population. ${ }^{1}$ Approximate SE estimated from variation between replicates in responses per generation of direct and correlated responses.

\begin{tabular}{|c|c|c|c|c|c|}
\hline Replicate & 1 & $\begin{array}{c}h_{w}^{2} \\
2\end{array}$ & Pooled & $t$ & $\begin{array}{c}h^{2} \\
\text { Pooled }( \pm S E)^{1}\end{array}$ \\
\hline $\begin{array}{l}5 \text { wk body wt } \\
5 \text { wk testis wt } \\
\text { Index } 1(0.54 \mathrm{~W}+0.112 \mathrm{~T}) \\
\text { Index } 2(0.54 \mathrm{~W}-0.112 \mathrm{~T})\end{array}$ & $\begin{array}{l}0.26 \\
0.54 \\
0.22 \\
0.54\end{array}$ & $\begin{array}{l}0.24 \\
0.38 \\
0.34 \\
0.54\end{array}$ & $\begin{array}{l}0.26 \\
0.48 \\
0.30 \\
0.54\end{array}$ & $\begin{array}{l}0.60 \\
0.54 \\
0.78 \\
0.70\end{array}$ & $\begin{array}{l}0.21(0.06) \\
0.44 \\
0.13(0.07) \\
0.32(0.04)\end{array}$ \\
\hline
\end{tabular}

heritability of index 2 than of index 1 would be if the environmental correlation were much higher than the genetic correlation.

\section{Analysis of growth}

The selected lines did not differ greatly from each other or from the controls in the general shape of their growth curves at generation 13. There were however some clear, but small, differences and more detailed analyses are necessary to demonstrate 
these. Therefore, in order to show the differences, mean weights of males of the selected lines are given in figures 6 and 7 for entire and castrate males, respectively, as a percentage of the weights of the corresponding controls at the same age. The control means are given in table IV. For example, both the entire and castrate males of the LL index line are about $10 \%$ smaller than those of its control at $21 \mathrm{~d}$, but only $2 \%$ smaller at $119 \mathrm{~d}$; whereas those of the LH line are also smaller than the controls, but relatively less so at 21 than $119 \mathrm{~d}$. Even at 17 wk when recording ceased, mice were still increasing in weight, presumably largely due to fat deposition. The line differences were however generally well established by that time.
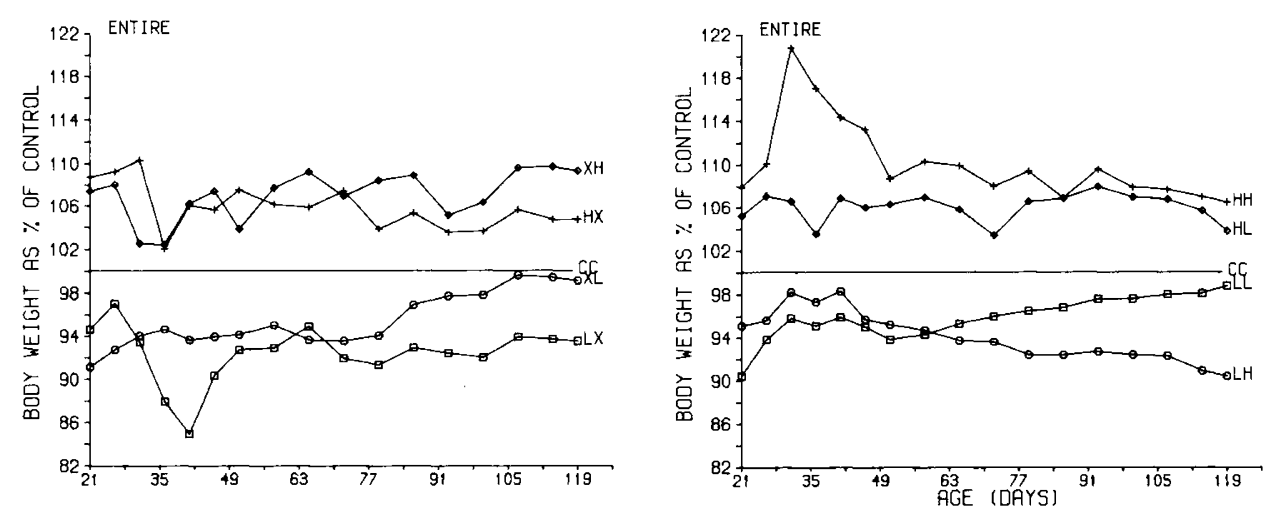

Fig 6. Body weight in generation 13 of entire males from 3-17 wk of age and averaged over replicates, expressed as a percentage of the corresponding control mean: left graph, lines selected on single trait; right graph, lines selected on indices.
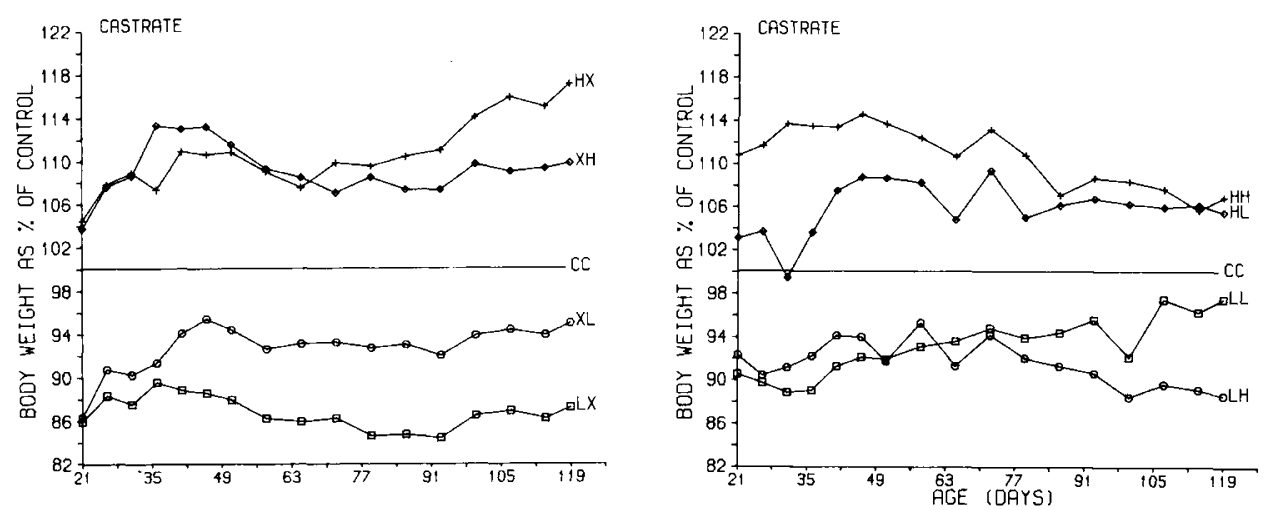

Fig 7. As figure 6 but for castrate males. 
Table IV. Control mean for body weight and control mean and contrasts in natural logarithms of body weight between divergent lines at generation 13, with additional contrasts at generation $7 .{ }^{1} 6,9,12$ and 15 wk records were taken at age $41,65,86$ and $107 \mathrm{~d}$, respectively, in generation $13 ;^{2} \mathrm{HBW}$-LBW is the mean difference between all lines selected high and low on body weight, ie (HX-LX + HH-LL + HL-LH)/3, and similarly HTW-LTW for all lines selected on testis weight. ${ }^{*} P<0.05,{ }^{* *} P<0.01$.

\begin{tabular}{|c|c|c|c|c|c|c|c|c|c|c|}
\hline \multicolumn{6}{|c|}{ Entire males } & \multicolumn{4}{|c|}{ Castrate males } & \multirow[b]{2}{*}{15} \\
\hline Age $(w k s)^{1}$ & 3 & 6 & 9 & 12 & 15 & 3 & 6 & 9 & 12 & \\
\hline \multicolumn{11}{|c|}{ Body weight $(g)$ - generation 13} \\
\hline CC mean & 11.3 & 27.4 & 33.2 & 35.7 & 37.1 & 11.6 & 24.3 & 30.6 & 33.6 & 34.9 \\
\hline \multicolumn{11}{|c|}{$100 \times \ln ($ body weight $(\mathrm{g}))$} \\
\hline \multicolumn{11}{|c|}{ Generation 13} \\
\hline CC mean & 243 & 331 & 350 & 358 & 361 & 245 & 319 & 342 & 351 & 355 \\
\hline \multicolumn{11}{|c|}{ Contrasts among pairs of lines } \\
\hline $\begin{array}{l}\text { HX-LX } \\
\text { XH-XL } \\
\text { HH-LL } \\
\text { HL-LH }\end{array}$ & $\begin{array}{l}13.7 \\
16.3 \\
25.4 \\
10.5\end{array}$ & $\begin{array}{l}22.3^{* *} \\
12.3^{*} \\
18.1^{*} \\
8.4\end{array}$ & $\begin{array}{l}11.3 \\
15.3 \\
15.3 \\
11.8\end{array}$ & $\begin{array}{l}13.0 \\
11.3 \\
10.5 \\
14.4\end{array}$ & $\begin{array}{r}12.1 \\
9.1 \\
10.6 \\
14.4\end{array}$ & $\begin{array}{l}20.4^{*} \\
18.4 \\
20.8^{*} \\
11.2\end{array}$ & $\begin{array}{l}22.5^{* *} \\
18.3^{*} \\
22.2^{* *} \\
13.4\end{array}$ & $\begin{array}{l}22.3^{* *} \\
15.0^{*} \\
17.0^{*} \\
13.6\end{array}$ & $\begin{array}{l}26.3^{* *} \\
14.0^{*} \\
12.8 \\
15.2^{*}\end{array}$ & $\begin{array}{l}{ }^{2} 28.8^{* *} \\
14.0^{*} \\
12.0^{*} \\
16.9^{* *}\end{array}$ \\
\hline SE & 9.2 & 7.3 & 7.9 & 8.9 & 7.9 & 9.3 & .7 .6 & 6.6 & 6.4 & 5.9 \\
\hline \multicolumn{11}{|c|}{ Contrasts among sets of lines } \\
\hline $\begin{array}{l}\text { HBW-LBW }{ }^{2} \\
\text { HTW-LTW }\end{array}$ & $\begin{array}{l}16.5^{*} \\
10.4\end{array}$ & $\begin{array}{l}16.3^{* *} \\
7.3\end{array}$ & $\begin{array}{c}{ }^{*} 12.8^{*} \\
6.3\end{array}$ & $\begin{array}{c}12.6^{*} \\
2.5\end{array}$ & $\begin{array}{c}12.4^{*} \\
1.8\end{array}$ & $\begin{array}{c}17.5^{*} \\
9.3\end{array}$ & $\begin{array}{l}19.4^{* * *} \\
9.0\end{array}$ & $\begin{array}{l}17.6^{* *} \\
6.1\end{array}$ & $\begin{array}{l}18.1^{* *} \\
3.9\end{array}$ & $\begin{array}{l}19.2^{* *} \\
3.0\end{array}$ \\
\hline SE & 5.3 & 4.2 & 4.6 & 5.1 & 4.6 & 5.4 & 4.4 & 3.8 & 3.7 & 3.4 \\
\hline \multicolumn{11}{|c|}{ Generation $\gamma$} \\
\hline $\begin{array}{l}\text { HBW-LBW } \\
\text { HTW-LTW }\end{array}$ & $\begin{array}{l}14.1^{* *} \\
2.4\end{array}$ & $\begin{array}{c}16.8^{*} \\
3.8\end{array}$ & $\begin{array}{l}15.2^{*} \\
-0.1\end{array}$ & $\begin{array}{l}{ }^{*} 15.5^{* *} \\
-1.5\end{array}$ & $\begin{array}{l}14.5^{* *} \\
-3.3\end{array}$ & $\begin{array}{c}12.2^{*} \\
1.8\end{array}$ & $\begin{array}{l}14.1^{*} \\
4.0\end{array}$ & $\begin{array}{l}13.2^{* *} \\
2.4\end{array}$ & $\begin{array}{l}15.6^{* *} \\
-0.5\end{array}$ & $\begin{array}{l}{ }^{*} 16.7^{* *} \\
-2.1\end{array}$ \\
\hline SE & 3.8 & 4.0 & 3.4 & 3.8 & 4.0 & 4.0 & 4.2 & 3.5 & 3.9 & 4.9 \\
\hline
\end{tabular}

An alternative to expressing body weights of 1 line as a ratio of those in another is to use logarithms, and particularly natural logs because when ratios $y / x$ ) are near unity, $\mathrm{y} / \mathrm{x}-1 \approx \ln \mathrm{y}-\ln \mathrm{x}$. Some contrasts between relevant pairs of lines are given in table IV (scaled up $\times 100$ to remove leading decimal zeros), and some data are included from the study of body weight taken at generation 7 , midway through the experiment. Apart from $6 \mathrm{wk}$ (strictly $41 \mathrm{~d}$ ) when LX mice were atypically small, the divergence in body weight between lines HX and LX, selected for body weight, was similar at different ages in the entire males, but tended to increase in the castrates. The divergence in body weight between $\mathrm{XH}$ and $\mathrm{XL}$, the testis weight selected lines, consistently decreased with age, as was the case between the index lines $\mathrm{HH}$ and LL, most notably at generation 13; these results could be expected if high testis weight lines matured earlier. In contrast, the divergence between the other index lines, $\mathrm{HL}$ and $\mathrm{LH}$, remained more constant, tending to increase with age. Because statistical tests were made against an error term including drift as 
estimated from differences between replicates with 8 degrees of freedom, only a small number of comparisons of weights were significant.

Relative maturity was computed as the ratio of body weight at 6 wk to that at $15 \mathrm{wk}$ for data from both generations 7 and 13 . (Records ceased at $15 \mathrm{w}$ in generation 7. In generation 13, records at 41 and $107 \mathrm{~d}$ were used). At 6 wh the mice had achieved about $70 \%$ of their 15-wk weight (table V). The lines selected for high testis weight, ie $\mathrm{XH}, \mathrm{HH}$ and $\mathrm{LH}$, were all relatively earlier maturing than the corresponding lines selected for low testis weight, ie XL, LL and HL, the difference being about $4 \%$ on average.

Table V. Relative maturity of males, expressed as (body weight at 6 wks)/(body weight at $15 \mathrm{wks})^{1}$ at generations 7 and $13 .{ }^{1} 6$ and 15 wk records taken at 41 and $107 \mathrm{~d}$ respectively in generation $13 ;{ }^{2}$ as table IV; ${ }^{*} P<0.05,{ }^{* *} P<0.01$.

\begin{tabular}{|c|c|c|c|c|c|c|c|c|c|}
\hline \multirow[b]{2}{*}{ Generation } & \multicolumn{2}{|c|}{ Entire } & \multicolumn{2}{|c|}{ Castrate } & & \multicolumn{2}{|c|}{ Entire } & \multicolumn{2}{|c|}{ Castrate } \\
\hline & 7 & 13 & 7 & 13 & & 7 & 13 & 7 & 13 \\
\hline & \multicolumn{9}{|c|}{ Relative maturity (\%) } \\
\hline $\begin{array}{l}\text { CC mean } \\
\text { HX } \\
\text { LX } \\
\text { XH } \\
\text { XL }\end{array}$ & $\begin{array}{l}70.8 \\
69.6 \\
69.2 \\
71.5 \\
66.9\end{array}$ & $\begin{array}{l}73.9 \\
74.3 \\
67.3 \\
71.8 \\
60.6\end{array}$ & $\begin{array}{l}62.1 \\
62.3 \\
67.2 \\
64.0 \\
60.2\end{array}$ & $\begin{array}{l}69.3 \\
66.3 \\
70.6 \\
71.8 \\
68.9\end{array}$ & $\begin{array}{l}\mathrm{CC} \\
\mathrm{HH} \\
\mathrm{LL} \\
\mathrm{HL} \\
\mathrm{LH}\end{array}$ & $\begin{array}{l}69.9 \\
74.6 \\
67.4 \\
70.3 \\
73.4\end{array}$ & $\begin{array}{l}74.0 \\
78.1 \\
72.6 \\
74.2 \\
78.5\end{array}$ & $\begin{array}{l}63.3 \\
67.7 \\
64.1 \\
62.2 \\
66.1\end{array}$ & $\begin{array}{l}70.3 \\
74.3 \\
67.0 \\
71.4 \\
73.9\end{array}$ \\
\hline Contrast & \multicolumn{9}{|c|}{ Contrasts in relative maturity (\%) } \\
\hline $\begin{array}{l}\text { HX-LX } \\
\text { XH-XL } \\
\text { HH-LL } \\
\text { HL-LH }\end{array}$ & $\begin{array}{c}0.4 \\
4.6 \\
7.2^{*} \\
-3.1\end{array}$ & $\begin{array}{r}6.9 \\
2.3 \\
5.5 \\
-4.2\end{array}$ & $\begin{array}{r}-4.8 \\
3.8 \\
3.6 \\
-4.0\end{array}$ & $\begin{array}{c}-4.3 \\
2.9 \\
7.3^{*} \\
-2.4\end{array}$ & $\begin{array}{l}\text { HBW-LBW }{ }^{2} \\
\text { HTW-LTW }\end{array}$ & $\begin{array}{l}1.5 \\
5.0^{*}\end{array}$ & $\begin{array}{l}2.7 \\
4.0\end{array}$ & $\begin{array}{r}-1.7 \\
3.8\end{array}$ & $\begin{array}{l}0.2 \\
4.2^{*}\end{array}$ \\
\hline $\mathrm{SE}$ & 3.1 & 4.1 & 3.2 & 2.9 & & 1.8 & 2.4 & 1.8 & 1.7 \\
\hline
\end{tabular}

Analyses of the records on food intake taken in generation 13 showed that the responses in gain were generally accompanied by similar proportional changes in food intake, so there were only trivial differences between the lines in food conversion efficiency (results not shown).

\section{Body composition}

Body composition was assessed from the ratio of fat pad weights (gonadal plus hind limb depots) to body weight on entire males of 11 wk of age in generation 10 , and from total chemical fat as a proportion of (wet) body weight on entire and castrate males of 5 and $17 \mathrm{wk}$ at generation 13 (table VI). The lines differed little in fat content at 5 wk. At later ages there was no very consistent pattern among those selected on body weight, but the lines selected for high testis weight were, on average, leaner than those selected for low testis weight, by about $4 \%$ in both entire and castrate males at $17 \mathrm{wk}$ of age. 
Table VI. Control mean and contrasts in fat as a proportion of wet body weight, either as gonadal plus hind limb fat pad weights (FPW/BW) on 11-wk-old entire males in generation 10, or as total chemical fat (Fat/BW) on 5 and 17-wk-old entire and castrate males in generation $13 .{ }^{*} P<0.05,{ }^{* *} P<0.01$; ${ }^{1}$ As table IV.

\begin{tabular}{|c|c|c|c|c|c|c|c|c|c|c|}
\hline & \multirow{2}{*}{$\begin{array}{r}1 \\
g W\end{array}$} & \multirow{2}{*}{$\begin{array}{l}11 \text { wks } \\
\text { entire } \\
F P W / B W \\
m g / g\end{array}$} & \multicolumn{4}{|c|}{$5 w k s$} & \multicolumn{4}{|c|}{$17 w k s$} \\
\hline & & & $\stackrel{B W}{g}$ & $\begin{array}{l}\text { entire } \\
\text { Fat } / B W \\
g / 100 g\end{array}$ & \multicolumn{2}{|c|}{\begin{tabular}{cc}
\multicolumn{2}{c}{ castrate } \\
$B W$ & Fat/BW \\
$g$ & $g / 100 g$
\end{tabular}} & \multicolumn{2}{|c|}{\begin{tabular}{cc}
\multicolumn{2}{c}{ entire } \\
$B W$ & Fat $/ B W$ \\
$g$ & $g / 100 g$
\end{tabular}} & \multicolumn{2}{|c|}{\begin{tabular}{cc}
\multicolumn{2}{c}{ castrate } \\
$B W$ & Fat/BW \\
$g$ & $g / 100 g$
\end{tabular}} \\
\hline CC mean & 34.2 & 23.0 & 24.1 & 8.4 & 22.3 & 9.5 & 37.7 & 13.6 & 35.6 & 20.2 \\
\hline \multicolumn{11}{|c|}{ Contrasts amongst pairs of lines } \\
\hline $\begin{array}{l}\text { HX-LX } \\
\text { XH-XL } \\
\text { HH-LL } \\
\text { HL-LH }\end{array}$ & $\begin{array}{l}6.7^{*} \\
3.1 \\
2.6 \\
5.4^{*}\end{array}$ & $\begin{array}{l}1.0 \\
0.4 \\
0.8 \\
6.2^{*}\end{array}$ & $\begin{array}{l}5.0 \\
5.8 \\
2.8 \\
3.2\end{array}$ & $\begin{array}{l}1.6 \\
0.6 \\
0.2 \\
1.0\end{array}$ & $\begin{array}{l}4.1 \\
4.2 \\
4.1 \\
1.5\end{array}$ & $\begin{array}{r}2.3 \\
-0.5 \\
0.4 \\
1.2\end{array}$ & $\begin{array}{l}4.7 \\
3.8 \\
2.9 \\
3.9\end{array}$ & $\begin{array}{l}-1.6 \\
-5.4^{*} \\
-4.2 \\
3.3\end{array}$ & $\begin{array}{l}11.5^{* *} \\
5.3 \\
3.0 \\
6.9^{*}\end{array}$ & $\begin{array}{c}8.1^{*} \\
-3.4 \\
-6.1 \\
2.7\end{array}$ \\
\hline $\mathrm{SE}$ & 2.3 & 2.3 & 1.7 & 0.9 & 2.0 & 1.1 & 4.1 & 2.3 & 2.7 & 3.3 \\
\hline \multicolumn{11}{|c|}{ Contrasts among sets of lines } \\
\hline $\begin{array}{l}\text { HBW- }^{-} \\
\text {LBW }^{1}\end{array}$ & $4.9^{* *}$ & 2.7 & $3.7^{* *}$ & * $\quad 0.9$ & $3.2^{*}$ & 1.3 & 3.8 & -0.8 & $7.1^{* *}$ & 1.6 \\
\hline $\begin{array}{l}\text { HTW- } \\
\text { LTW }\end{array}$ & 0.1 & -1.7 & 1.8 & -0.1 & 2.3 & -0.4 & 0.9 & $-4.3^{*}$ & 0.5 & -4.1 \\
\hline SE & 1.3 & 1.3 & 1.0 & 0.5 & 1.2 & 0.6 & 2.4 & 1.3 & 1.6 & 1.9 \\
\hline
\end{tabular}

\section{DISCUSSION AND CONCLUSION}

The objective of this experiment was to check the hypothesis which arose from the experiment with sheep (Land et al, 1980) that the pattern of growth could be altered by using a measure of maturity such as testis size on immature animals. Undoubtedly such a change was effected, perhaps seen most clearly by the ratio of 6-15 wks in table $\mathrm{V}$ for the mean comparisons of maturity of high and low testis weight lines, which differed by about $4 \%$ around a mean of $70 \%$. Nevertheless, the results were not "spectacular": they are not clearly seen in simple plots of body weight against age, so the derived results shown in figures 6-7 were necessary.

One of the more striking aspects of the growth curve analyses is that very similar changes were effected in both entire and castrated males (see table V), and analyses (Williams, 1984, not tabulated) at generation 7 yielded similar results for females as for males. This implies that the presence of the testis after $19 \mathrm{~d}$, the age of castration at generation 13, and circulating testosterone are not required for the growth curves to change. Estimates of testosterone levels were made on 5 and 10-wk-old mice by the method of radioimmune assay of Webb et al (1985). Differences between lines were, however, small compared to error from natural and assay variation, for correlations of line means on successive samplings were low $(<0.5)$, and no clear differences were found (results not shown). In addition, age at sexual maturity of males was assessed in replicate 1 (there was not time to repeat in replicate 2) by caging young males each with several sexually mature females, and recording 
the day of first copulatory plug. The control mean was $43.5 \mathrm{~d}$, and the contrasts were $\mathrm{HX}-\mathrm{LX}=-2.0, \mathrm{XH}-\mathrm{XL}=4.4, \mathrm{HH}-\mathrm{LL}=-1.2, \mathrm{HL}-\mathrm{LH}=4.7$, each with $\mathrm{SE}$ of 1.1 including only within replicate error. In summary, the mean for high testis weight lines was $0.5 \mathrm{~d}$ less than for low testis weight lines, a trivial difference (a few mice did not plug by $49 \mathrm{~d}$, when recording ceased, but accounting for them would not influence this conclusion). It is therefore unclear from this experiment that the change in testis weight induced changes in growth rate as a specific indicator of sexual maturity or directly through its hormonal action. Alternatively, testis weight in relation to body weight might simply be an indicator of allometric growth of internal organs, and that high ratios of weights of several organs to body weight are an indicator of approaching maturity.

In the experiment with sheep (Land et $a l, 1980$ ), the selection criterion was testis weight averaged over 3 ages, 6, 10 and $14 \mathrm{wk}$, adjusted by phenotypic regression on body weight at these ages (Haley et al, 1989). Thus they were, in effect, selected on an index of high testis weight and low body weight at these ages and the changes in body weight could largely be due to selection on body weight. Haley et al (1990) calculate however, that the genetic correlation between their selection criterion in males and body weight in females became increasingly negative with successive years of age of the female, whereas simple negative selection on body weight might be expected to give a different trend.

Correlated responses in reproductive performance are described in a subsequent paper (Hill et al, 1990), but these are relevant to the discussion of what influences mature size. Briefly, positive correlated responses in litter size were obtained with selection on body weight alone, testis weight alone, and on the index of the traits in the same direction (HH-LL), but not when selected in opposite directions (HL-LH). The analyses undertaken on those results indicate that selection on testis weight influenced litter size, even after correction for body weight, in accordance with the results of Eisen and Johnson (1981) and suggesting that testis size is indeed an indicator of development in some specific way, as Land (1973) proposed.

From the results of this experiment it is not possible to directly compare the accuracy of selection including records on testis weight of immature animals to that including body weight on mature animals, without estimates of genetic variances and covariances of weights except at $5 \mathrm{wks}$. If the intention were to increase an early weight and hold a later weight constant, the response would then be a little less than $\left(1-r_{G}^{2}\right)^{1 / 2}$ of that with selection for the early weight alone, where $r_{G}$ is the genetic correlation. For 5 and 10 wk body weight, Hayes and McCarthy (1976) obtained $r_{G}=0.8$, for which $\left(1-r_{G}^{2}\right)^{1 / 2}=0.6$. Nevertheless, lines selected on testis weight and on the indices of $5 \mathrm{wk}$ body weight and testis weight gave similar responses in 5 wk body weight as did the lines selected solely for that trait and lower but not zero responses at later ages. Five-wk body weight had a rather low heritability, both to within family selection and also when converted to mass selection, substantially lower than for testis weight; therefore testis weight was a better predictor of body weight than vice versa. This may not apply to other species. The index of practical interest, ie increasing body weight and testis weight $(\mathrm{HH})$, similarly had a low heritability, particularly for mass selection because the intra-class correlation of sibs was high. Furthermore, there were large differences between replicates, particularly 
in the correlated responses of the index lines and apparent discrepancies between genetic correlations of body weight and testis weight among the sets of lines.

Whilst there was reasonably good evidence to suggest that mature weights were reduced by selection on testis weight relative to body weight, indicating that such animals matured earlier, the fairly clear observation that they were also leaner was rather surprising because, in farm animals, early maturity is usually associated with higher degrees of fatness when comparisons are made at constant age. There is no evidence that the high testis weight selection led to any restriction of appetite which might have effected this; nor is there any obvious mechanism.

In conclusion selection on testis weight led to some changes in the shape of the growth curve. That these were not marked is not surprising in view of the high correlation between weights at different ages. At this stage we would not, however, advocate selection to be practised on testis weight to change degree of maturity. It tis likely to be safer to select directly on weights at different ages; and if selection decisions need to be made early in the animal's life, records of older relatives such as parents and uncles can be used.

\section{ACKNOWLEDGMENTS}

This work was supported by a grant from the Agricultural and Food Research Council. We are very grateful to Roberta Wallace, Ann Walker and staff of the mouse house for technical assistance and to Gene Eisen, Douglas Falconer and Chris Haley for comments on a draft of the paper. Roger Land initiated the experiment reported here and died after lab work had been completed. He is greatly missed.

\section{REFERENCES}

Abplanalp H, Ogasawara FX, Asmundson VS (1963) Influence of selection for body weight at different ages on growth of turkeys. Br Poult Sci 4, 71-82

von Butler I, Duda J, Anmann J (1986) Effects of divergent and antagonistic selection for body weight on sexual maturity in female mice. $Z$ Versuchstierkunde 28, 187-192

von Butler I, Willeke H, Pirchner F (1980) Preliminary results on antagonistic selection in mice. In: Selection Experiments in Laboratory and Domestic Animals (Robertson A, ed) Commonwealth Agricultural Bureau, Slough, 114-117

Eisen EJ, Johnson BH (1981) Correlated responses in male reproductive traits in mice selected for litter size and body weight. Genetics $99,513-524$

Falconer DS (1973) Replicated selection for body weight in mice. Genet Res 22, 291-321

Falconer DS (1989) Introduction to Quantitative Genetics, 3rd ed Longman, Harlow

Haley CS, Lec GJ, Fordyce M, Land RB Selection for testis size adjusted for body weight in male lambs: Direct responses in males and correlated responses for reproduction in females. $J$ Reprod Fert (submitted) 
Hayes JF, McCarthy JC (1976) The effects of selection at different ages for high and low body weight on the pattern of fat deposition in mice. Genet Res 27, 389-433

Hill WG, Marks PJ, Jenkins JC, Land RB (1990) Selection on testis size as an indicator of maturity in growing animals. II Correlated responses in reproductive rate. Genet Sel Evol 22, 247-254

Islam ABMM, Hill WG, Land RB (1976) Ovulation rate in lines of mice selected for testis weight. Genet Res 27, 23-32

Land RB (1973) The expression of female sex limited characters in the male. Nature 241, 208-209

Land RB, Carr WR, Lee GJ (1980) A consideration of physiological criteria of reproductive merit in sheep. In: Selection Experiments in Laboratory and Domestic Animals (Robertson A, ed) Commonwealth Agricultural Bureau, Slough, $147-160$

Lee GJ, Land RB (1985) Testis size and LH response to LH-RH as male criteria of female reproductive performance. In: Genetics of Reproduction in Sheep (Land RB, Robinson DW, eds) Butterworths, London, 333-341

Lee GJ, Haley CS (1990) Body weight adjusted testis size as a selection criterion to improve production efficiency in sheep. Proc 4th World Congr Genet Appl Livest Prod (in press)

McCarthy JC, Doolittle DP (1977) Effects of selection for independent changes in two highly correlated body weight traits of mice. Genet Res 29, 133-145

Marks PJ (1988) Direct and correlated responses to selection to change the shape of the growth curve in mice. $\mathrm{PhD}$ Thesis, University of Edinburgh

Ricard FH (1975) Essai de sélection sur la forme de la courbe de croissance chez le poulet. Ann Génét Sél Anim 7, 427-443

Sharp GL, Hill WG, Robertson A (1984) Effects of selection on growth, body composition and food intake in mice. I. Responses in selected traits. Genet Res 43, 75-92

Webb R, Baxter G, McBride D, Nordblom GD, Shaw MKW (1985) The measurement of testosterone and oestradiol - 17B using iodinated tracers and incorporating an affinity chromatography extraction procedure. J Steroid Biochem 23, 1043-1051

Williams JC (1984) Influence of selection for body weight and testis weight on the growth of mice. $\mathrm{PhD}$ Thesis, University of Edinburgh

Wilson SP (1973) Selection for ratio of body weight gains in mice. J Anim Sci 37, 1098-1103

\section{APPENDIX}

\section{Estimates of genetic correlation}

From the within-family heritability estimates $\left(h_{w}^{2}\right)$ of table III, the direct $(R)$ and correlated $(C)$ responses in table II and the within family standard deviations, 
estimates of genetic variances $\left(V_{A}\right)$, genetic covariances $\left(\operatorname{Cov}_{A}\right)$ and genetic correlations $\left(r_{A}\right)$ were obtained, where $W=$ body weight $(\mathrm{g})$ and $T=$ testis weight $(\mathrm{mg})$, and the units of the indices are arbitrary. From the single trait lines, $V_{A W}=$ $2(0.26)(1.82)^{2}=1.72$ and $V_{A T}=76$, and thus $\operatorname{Cov}_{A W T}=\left(C_{T} / R_{W}\right) V_{A W}=10.1$ or $\operatorname{Cov}_{A W T}=\left(C_{W} / R_{T}\right) V_{A T}=8.2$, with a mean of 9.1, corresponding to $r_{A W T}=0.80$, as in the text. From the index lines, $V_{A I 1}=1.69$ and $V_{A I 2}=1.24$ and thus $\operatorname{Cov}_{A I 1 I 2}=\left(C_{I 2} / R_{I 1}\right) V_{A I 1}=-0.52$ or $\operatorname{Cov}_{A I 1 I 2}=\left(C_{I 1} / R_{I 2}\right) V_{A I 2}=-0.18$, with mean -0.35 , giving $r_{A I 112}=-0.24$.

Predictions of index variances and covariances from the single trait lines and vice versa can also be made. Letting $b_{1}=0.54$ and $b_{2}=0.112$ be the index weights, then: $V_{A I 1}=b_{1}^{2} V_{A W}+2 b_{1} b_{2} \operatorname{Cov}_{A W T}+b_{2}^{2} V_{A T}, V_{A I 2}=b_{1}^{2} V_{A W}-2 b_{1} b_{2} \operatorname{Cov}_{A W T}+b_{2}^{2} V_{A T}$ and $\operatorname{Cov}_{A I 1 I 2}=b_{1}^{2} V_{\mathrm{AW}}-b_{2}^{2} V_{A T}$ and thus, for example, $V_{A W}=\left(V_{A I 1}+V_{A I 2}+\right.$ $\left.2 \operatorname{Cov}_{A I 1 I 2}\right) /\left(4 b_{1}^{2}\right)$. Predicting from the single trait lines: $V_{A I 1}=2.56, V_{A I 2}=$ $0.35, \operatorname{Cov}_{A I 1 I 2}=-0.45$ and $r_{A 11 I 2}=0.48$; and predicting from the index lines, using the mean estimate of $\operatorname{Cov}_{A I 1 I 2}=-0.35: V_{A W}=1.90, V_{A T}=73, \operatorname{Cov}_{A W T}=$ 1.90 corresponding to $r_{A W T}=0.17$, which contrasts with the estimate of 0.80 from the single trait lines. 